\title{
In vitro organogenesis and plant regeneration of Passiflora xishuangbannaensis, a species with extremely small populations
}

\section{Yuan-yuan Meng}

XTBG: Xishuangbanna Tropical Botanical Garden

\section{Shi-jie Song}

University of Chinese academy of sciences

Sven Landrein ( $\square$ sven@xtbg.ac.cn )

XTBG: Xishuangbanna Tropical Botanical Garden https://orcid.org/0000-0003-0028-2450

\section{Research Article}

Keywords: Passiflora, Organogenesis, Callus, Plant Growth Regulators, ISSR

Posted Date: May 3rd, 2021

DOl: https://doi.org/10.21203/rs.3.rs-360926/v1

License: () (1) This work is licensed under a Creative Commons Attribution 4.0 International License. Read Full License 


\section{Abstract}

Passiflora xishuangbannaensis (Passifloraceae) is endemic to a few sites of Mengyang nature reserve in Yunnan, Xishuangbanna and less than 40 individuals have been recorded. Nine Passiflora species are endemic to Yunnan with most species occurring in South America, making P. xishuangbannaensis highly significant and emblematic to the conservation work in the region. This study is designed to provide the first protocol for in vitro organogenesis and plant regeneration for ex situ conservation and reintroduction for an Asian Passiflora species. Using internodes, petioles and tendrils we optimize calli formation and root elongation using several plant growth regulators, individually or in combination. We also assess the genetic stability of regenerated cells. The maximum callus induction and shoot bud differentiation were both achieved on half Murashige and Skoog basal medium supplemented with $4.44 \mu \mathrm{M}$ 6-Benzylaminopurine and $1.08 \mu \mathrm{M}$ 1-Naphthaleneacetic acid. The best rooting was achieved from 30 days old, regenerated shoots on half Murashige and Skoog basal medium supplemented with $1.08 \mu \mathrm{M}$ 1-Naphthaleneacetic acid. Micropropagated plants were subjected to inter simple sequence repeat markers analyses. Collectively, 86 bands were generated from 6 primers of which 12 bands were polymorphic, showing genetic variation between the regenerated plantlets and the original plant. Response to plant growth regulators was more specific than most other studies using South American species, which could be explained by the morphological and physiological differences between South American and Asian Passiflora species

\section{Introduction}

Passiflora L. is the largest genus in Passifloraceae with more than 600 species (Espinoza et al. 2018). Passiflora xishuangbannaensis Krosnick is a rhizomatous species with weak herbaceous stems, belonging to supersection Disemma (Labill.) J.M.MacDougal \& Feuillet section Octandranthus Harms (Krosnick 2005). Most Passiflora species occur in Central and South America, with only 22 species occurring in Southeast Asia, Australia and the Pacific Islands (Krosnick \& Fredeustein 2005). In China, nine species are native to Yunnan, of which three species are endemic to Xishuangbanna and Pu'er alone ( $P$. altebilobata Hemsl., $P$. xishuangbannaensis and P. menghaiensis X.D.Ma, L.C.Yan \& J.Y.Shen, Ma et al. 2019).

During the investigation of this project, we surveyed all known sites of Passiflora xishuangbannaensis. A total of 38 individuals were counted from 5 sites of which 2 sites did not have plants anymore. This species is below the Minimum Viable Population (MVP) size, with less than 5000 individuals in total and less than 500 individuals per population and qualify for the Plant Species with Extremely Small Population PSESP (Sun et al. 2019). Furthermore, this species was also reported to be self-incompatible (Krosnick 2005), and rarely sets fruit in the wild, causing a decline in natural population size.

In vitro regeneration and multiplication is a technique that can reproduce plants using organs, tissues or cells with a high success rate, it can also be used to obtain disease-free offspring (González-Benito \& Martín 2011). This technique has been used in rare plant conservation strategies and has been studied for ex situ conservation of threatened species in many plant families (Sheelavantmath et al. 2000; Ayuso et al. 2019; Rodrigues et al. 2020). Passiflora xishuangbannaensis growth was shown to be enhanced by grafting on $P$. edulis Sims. stock (Fu Chuan Wu, personal communication, 2020), however no long-term methods have been developed to propagate this species and no information is known about its in vitro regeneration. 
Several studies on Passiflora tissue culture have been conducted, and many successful cases of regeneration by organogenesis have been reported from a wide range of species (Fernando et al. 2007; Pinto et al. 2010; Silva et al. 2011; Faria et al. 2018). Data from previous studies suggest that many factors could influence the results of in vitro propagation, such as explant type, Plant Gowth Regulators PGR, media composition and plant growth regulators. Successful organogenesis protocols have been established from different types of explants, such as leaves, roots, hypocotyls, stem nodes, internode segments or even petioles and tendrils (Mast et al. 2007; Pipino et al. 2010; Ozarowski et al. 2013; Vieira et al. 2014; Shekhawat et al. 2015). Besides explants, PGRs were the most frequently studied factors affecting organogenesis of Passiflora. Among all the plant growth regulators used, the synthetic cytokinin 6-benzylaminopurine (benzyl adenine, BA) alone or combined with the synthetic auxin 1-Naphthaleneacetic Acid (NAA) were frequently used in in vitro organogenesis and confirmed to be effective (Dias et al.2009; Pipino et al. 2010; Rocha et al. 2012).

Previous studies found that regenerated plants are genetically stable (Venkatachalam et al. 2007; Asthana et al. 2011; Chavan et al. 2015). However, some studies have shown genetic alterations during in vitro regeneration (Naseer \& Mahmood 2014; Krishna et al. 2016). These alterations might be due to mutagenesis during the breakdown of normal cellular controls (Phillips et al.1994), or accumulation of somatic mutations induced by several factors including the various concentrations and types of PGRs used during the tissue culture period (Martin et al. 2006; Bairu et al. 2011). Molecular markers, such as Simple Sequence Repeat (SSR), Inter Simple Sequence Repeat (ISSR), Random Amplified Polymorphic DNA (RAPD), Start Codon Targeted (SCoT) polymorphism, Inter-retrotransposon Amplified Polymorphism (IRAP), and Amplified Fragment Length Polymorphism (AFLP), have been confirmed to be informative in studies on genetic diversity and activities related to the conservation of genetic resources (Bornet and Branchard 2001; Campbell et al. 2011; Wang et al. 2013; Rahmani et al. 2015; Al-Qurainy et al. 2018; Rodrigues et al. 2020). Among these molecular markers, ISSR was emphasized because it has good reproducibility and does not require prior knowledge of the primer sequence nor high amounts of DNA (Kumar et al. 2009; Saoza et al. 2015).

The present study aims to establish an efficient in vitro organogenesis protocol to produce regenerated plants of $P$. xishuangbannaensis. The differential responses of BA alone or combined with NAA is evaluated for in vitro organogenesis, using internodal segments, petioles and tendrils as explants. Different NAA concentrations are also evaluated for in vitro rooting of regenerated shoots. Additionally, the genetic stability of regenerated plants from three types of explant is assessed using ISSR markers.

\section{Materials And Methods}

\section{Explant preparation}

Stems of Passiflora xishuangbannaensis were collected from plants cultivated in a greenhouse of Xishuangbanna Tropical Botanical Garden (XTBG; China). In our preliminary experiment, almost all leaf fragments became polluted because of the endophytes in the leaves. Therefore, we discarded leaf fragments in the following experiments. Internodal segments (Ins), petioles (Pts) and tendrils (Tds) were excised from the stems. All explants were surface sterilized with $1 \% \mathrm{NaClO}(\mathrm{w} / \mathrm{v})$ for $8 \mathrm{~min}$ and rinsed 3-4 times with sterilized distilled water to remove trace $\mathrm{NaClO}$. After sterilization, the three types of explants were cut into 0.5 cm-long segments. 


\section{Callus induction and in vitro shoot regeneration}

Half strength (1/2) MS medium (Murashige and Skoog 1962) supplied with $3 \%(\mathrm{w} / \mathrm{v})$ sucrose, $0.1 \%(\mathrm{w} / \mathrm{v})$ $0.7 \%(\mathrm{w} / \mathrm{v})$ agar and activated charcoal were used as the medium for all experiments. To test the effect of BA alone or in combination with NAA on the induction of callus and shoots of different explants, media were supplied with BA at three different concentrations $(2.22,4.44$ or $8.88 \mu \mathrm{M})$ alone or in combination with NAA at two different concentrations $(0.54$ or $1.08 \mu \mathrm{M})$. Medium without any plant growth regulators was used as control. Each treatment was replicated 10 times, and six explants were placed in each petri dish. Medium was autoclaved at $121^{\circ} \mathrm{C}$ for $20 \mathrm{~min}$., and PGRs were filtered through a $0.22 \mu \mathrm{m}$ membrane (Millipore, MA, USA) to remove microorganism before they were added into the medium. Cultures were incubated at $25 \pm 2^{\circ} \mathrm{C}$ with a 12/12-h light/ dark cycle. The status of callus and shoot induction was assessed 45 days after incubation.

\section{In vitro rooting and acclimatization}

To test the effect of NAA on the induction of roots from regenerated shoots, 30 days old, regenerated shoots were placed on $1 / 2 \mathrm{MS}$ medium with NAA at different concentrations $(0,0.54,1.08$ and $1.62 \mu \mathrm{M})$. Cultures were incubated at $25 \pm 2^{\circ} \mathrm{C}$ and $80-90 \%$ relative humidity, with a 12/12-h light/ dark cycle. Data on the rooting frequency and growth were recorded after 30 days of culture.

Before transferring to a sterilized nutritive soil (Chunnian, China), In vitro regenerated and well-rooted plantlets were taken out of the glass bottles and the roots were washed using tap water to remove the medium adhering to them. The plants were left in a laminar flow cabinet to remove the residual water from the root surface, before transferred to the soil and incubated at $25 \pm 2^{\circ} \mathrm{C}$ and $70-80 \%$ relative humidity, with a $12 / 12-\mathrm{h}$ light/ dark cycle.

\section{Genetic Fidelity Assessment}

The genomic DNA was isolated from fresh leaf of 9 randomly selected regenerated plants and 1 mother plant using EasyPure Plant Genomic DNA Kit (TransGen Biotech, China). ISSR technique was used to analyze genetic fidelity among regenerated plants (Zietkiewicz et al. 1994). A total of 18 ISSR primers were tested and six were selected in the analysis. The amplification program was as follows: initial DNA denaturation for 5 min at $95^{\circ} \mathrm{C}$, followed by 38 cycles at $94^{\circ} \mathrm{C}$ for $1 \mathrm{~min}$, annealing for $1 \mathrm{~min}$ at $54-61.7^{\circ} \mathrm{C}$ depending on the primer (Table 1), elongation for $2 \mathrm{~min}$ at $72^{\circ} \mathrm{C}$ followed by final extension at $72^{\circ} \mathrm{C}$ for $10 \mathrm{~min}$. The amplified fragments of DNA were separated on a $1.7 \%(\mathrm{w} / \mathrm{v})$ agarose gel. The amplified bands for each primer were counted as present (1) or absent (0) for ISSR analysis. Excel 2016 was used to calculate the total number of bands, the number of polymorphic bands, and the percentage of polymorphic bands. 
Table 1

ISSR primers used in the genetic fidelity study.

\begin{tabular}{|lllll|}
\hline Primer identification & Sequences $\left(\mathbf{5}^{\prime} \mathbf{3}^{\prime}\right)$ & $\mathrm{Tm}\left({ }^{\circ} \mathrm{C}\right)$ & $\mathrm{TB}$ & $\mathrm{PB}$ \\
\hline 1 & ACACACACACACACACCT & 58.9 & 20 & 4 \\
\hline 2 & AGAGAGAGAGAGAGAGYA & 54.1 & 16 & 3 \\
\hline 3 & GAGAGAGAGAGAGAGAYT & 58.9 & 13 & 1 \\
\hline 5 & GAGAGAGAGAGAGAGAGACC & 58.9 & 14 & 0 \\
\hline 6 & GAGAGAGAGAGAGAGARC & 60.1 & 14 & 4 \\
\hline Total & ACACACACACACACACG & 61.7 & 9 & 0 \\
\hline Tm $\left({ }^{\circ} \mathrm{C}\right)$ annealing temperature, TB total bands, PB polymorphic bands. & \\
\hline
\end{tabular}

\section{Statistical Analysis}

The callus induction and shoot regeneration were analyzed after 45 days of culture using two-way Analysis Of Variance (ANOVA), and root induction after one month from 30-d-old regenerated shoots was analyzed using one-way ANOVA. We used the Tukey's tests for multiple comparisons among treatments. All data presented are means \pm standard deviation. All statistical analyses were performed in R software environment (version 3.3.3). The alpha-type I error was fixed at 0.05 (thus, all non-significant differences have $P>0.05$ ).

\section{Results}

\section{Callus and shoot induction}

In this experiment, calli cannot be induced from any of the three types of explants (Ins, Pts and Tds) on $1 / 2$ MS medium or $1 / 2$ MS medium supplied with BA alone (from 2.22 to $8.88 \mu \mathrm{M}$ ). By contrast, calli are achieved from all explant types cultured in $1 \frac{1}{2}$ MS medium supplied with $4.44 \mu \mathrm{M}$ BA and $0.54 \mu \mathrm{M}$ NAA or with $4.44 \mu \mathrm{M}$ BA and $1.08 \mu \mathrm{M}$ NAA (Fig. 1a,b,c; Table 2). According to our observations, calli started to form after 7 days of culture in these two treatments. After 45 days of culture, the best results of calli induction are seen with Ins, Pts and Tds on $1 \frac{1}{2}$ MS medium supplemented with $4.44 \mu \mathrm{M}$ BA and $1.08 \mu \mathrm{M}$ NAA, resulting in a callus induction frequency of $91.67 \pm 11.7 \%, 90.00 \pm 14.05 \%$ and $88.33 \pm 11.25 \%$, respectively (Table 2 ). When we did multiple comparisons analysis among treatments and explant types, we found no differences in callus induction among the three explant types or the two treatments (Fig. 2a). Optimal growth of callus is achieved with $1 / 2$ MS medium supplemented with $4.44 \mu \mathrm{M}$ BA and $1.08 \mu \mathrm{M}$ NAA, resulting in a fresh weight of callus of $1.58 \pm 0.22,1.17 \pm 0.11$ and $0.71 \pm 0.11 \mathrm{~g}$, respectively (Table 2 ). And the highest callus fresh weight occurs with Ins, which is significantly higher than Pts and Tds (Fig. 2b). 
Table 2

Effect of BA alone or its combination with NAA on the induction of callus and shoots of different explants after 45 days of incubation.

\begin{tabular}{|c|c|c|c|c|c|c|c|c|c|}
\hline \multirow{2}{*}{$\begin{array}{l}\text { Treatment } \\
1 / 2 \mathrm{MS}+ \\
\text { PGR } \\
(\mu \mathrm{M})\end{array}$} & \multicolumn{3}{|c|}{ Internodal segments (Ins) } & \multicolumn{3}{|c|}{ Petiole segments (Pts) } & \multicolumn{3}{|c|}{ Tendril segments (Tds) } \\
\hline & $\begin{array}{l}\text { Callus } \\
\text { (\%) }\end{array}$ & $\begin{array}{l}\text { Callus } \\
\text { FW } \\
\text { (g) }\end{array}$ & $\begin{array}{l}\text { No } \\
\text { Shoots/ } \\
\text { Explant }\end{array}$ & $\begin{array}{l}\text { Callus } \\
(\%)\end{array}$ & $\begin{array}{l}\text { Callus } \\
\text { FW } \\
\text { (g) }\end{array}$ & $\begin{array}{l}\text { No } \\
\text { Shoots/ } \\
\text { Explant }\end{array}$ & Callus(\%) & $\begin{array}{l}\text { No } \\
\text { Shoots/ } \\
\text { Explant }\end{array}$ & $\begin{array}{l}\text { Callus } \\
\text { FW } \\
\text { (g) }\end{array}$ \\
\hline $\begin{array}{l}\text { Without } \\
\text { PGR }\end{array}$ & $0 \pm 0^{b}$ & & & $0 \pm 0^{b}$ & & & $0 \pm 0^{b}$ & & \\
\hline BA 2.22 & $0 \pm 0^{b}$ & & & $0 \pm 0^{b}$ & & & $0 \pm 0^{b}$ & & \\
\hline $\begin{array}{l}\text { BA } 2.22+ \\
\text { NAA } 0.54\end{array}$ & $0 \pm 0^{b}$ & & & $0 \pm 0^{b}$ & & & $0 \pm 0^{b}$ & & \\
\hline $\begin{array}{l}\text { BA } 2.22+ \\
\text { NAA } 1.08\end{array}$ & $0 \pm 0^{b}$ & & & $0 \pm 0^{b}$ & & & $0 \pm 0^{b}$ & & \\
\hline BA 4.44 & $0 \pm 0^{b}$ & & & $0 \pm 0^{b}$ & & & $0 \pm 0^{b}$ & & \\
\hline $\begin{array}{l}\text { BA } 4.44+ \\
\text { NAA } 0.54\end{array}$ & $\begin{array}{l}78.3 \\
\pm \\
19.3^{a}\end{array}$ & $\begin{array}{l}1.4 \pm \\
0.1^{\mathrm{a}}\end{array}$ & $\begin{array}{l}11.0 \pm \\
5.0^{\mathrm{a}}\end{array}$ & $\begin{array}{l}80.0 \\
\pm \\
20.5^{a}\end{array}$ & $\begin{array}{l}1.1^{ \pm} \\
0.1^{\mathrm{a}}\end{array}$ & $\begin{array}{l}11.0 \pm \\
5.1^{\mathrm{a}}\end{array}$ & $\begin{array}{l}76.7 \pm \\
22.5^{a}\end{array}$ & $\begin{array}{l}10.8 \pm \\
5.7^{\mathbf{a}}\end{array}$ & $\begin{array}{l}0.7 \pm \\
0.1^{\mathrm{a}}\end{array}$ \\
\hline $\begin{array}{l}\text { BA } 4.44+ \\
\text { NAA } 1.08\end{array}$ & $\begin{array}{l}91.7 \\
\pm \\
11.8^{a}\end{array}$ & $\begin{array}{l}1.6 \pm \\
0.2^{\mathrm{a}}\end{array}$ & $\begin{array}{l}12.1 \pm \\
6.2^{\mathrm{a}}\end{array}$ & $\begin{array}{l}90.0 \\
\pm \\
14.1^{\mathrm{a}}\end{array}$ & $\begin{array}{l}1.2^{ \pm} \\
0.1^{\mathrm{a}}\end{array}$ & $\begin{array}{l}12.7 \pm \\
6.0^{\mathrm{a}}\end{array}$ & $\begin{array}{l}88.3 \pm \\
11.3^{\mathbf{a}}\end{array}$ & $\begin{array}{l}10.7 \pm \\
6.7^{\mathrm{a}}\end{array}$ & $\begin{array}{l}0.7^{ \pm} \\
0.1^{\mathrm{a}}\end{array}$ \\
\hline BA 8.88 & $0 \pm 0^{b}$ & & & $0 \pm 0^{b}$ & & & $0 \pm 0^{b}$ & & \\
\hline $\begin{array}{l}\text { BA } 8.88+ \\
\text { NAA } 0.54\end{array}$ & $0 \pm 0^{b}$ & & & $0 \pm 0^{b}$ & & & $0 \pm 0^{b}$ & & \\
\hline $\begin{array}{l}\text { BA } 8.88+ \\
\text { NAA } 1.08\end{array}$ & $0 \pm 0^{b}$ & & & $0 \pm 0^{b}$ & & & $0 \pm 0^{b}$ & & \\
\hline
\end{tabular}

Shoots can be induced directly after 30 days from the calli in media supplied with $4.44 \mu \mathrm{M} B A$ and $0.54 \mu \mathrm{M}$ NAA or with $4.44 \mu \mathrm{M} B A$ and $1.08 \mu \mathrm{M}$ NAA, the latter is the best for shoot induction for all explant types with a shoot number of $12.09 \pm 6.17$ for Ins, $12.69 \pm 5.97$ for Pts and $10.71 \pm 6.67$ for Tds (Table 2). But no significant differences in the number of shoots are observed among the three explant types (Fig. 2c).

\section{In vitro rooting}

Healthy roots can be formed after 30 days of transferring to a rooting medium. Among all treatments $(0,0.54$, 1.08 and $1.62 \mu \mathrm{M} \mathrm{NAA}$ ), best rooting is achieved by transferring the shoots onto a rooting medium containing $1.08 \mu \mathrm{M}$ NAA (Fig. 1h), with the average root number of $5.25 \pm 1.94$ (Fig. 3a), and the average root length of $3.10 \pm 0.79 \mathrm{~mm}$ (Fig. $3 \mathrm{~b}$ ), although the root length is not significantly longer than with addition of $0.54 \mu \mathrm{M}$ NAA $(2.38 \pm 1.56) .1$

\section{Genetic fidelity}


Initially, 18 ISSR primers were tested for amplification. Of these, 6 primers give clear, unambiguous amplified DNA bands among mother plants and regenerated plants (Fig. 4). A total of 86 amplified bands ranging from $200 \mathrm{bp}$ to $4000 \mathrm{bp}$ are scored, with an average of 14 bands per primer. Among the 86 amplified bands, 12 are polymorphic, resulting in $13.95 \%$ genetic variation among mother pants and regenerated plants (Table 1 ).

\section{Discussion}

Leaves, roots, hypocotyls, internodes, petioles and nodal segments were frequently used explants in Passiflora organogenesis (Ozarowski and Thiem 2013 Mast et al. 2007; Lombardi et al. 2007). A few studies used leaves from plants grown in a greenhouse (Pinto et al. 2010), but in our preliminary experiment, almost all leaf fragments collected from a greenhouse became polluted because of the endophytes in the leaves, even if Plant Preservation Mixture (PPM) was used (data not shown). Leaves of some Passiflora species are confirmed to be inhabited by a microbial community of endophytes (Henrique et al. 2020).

In our study, we used internodes, petioles and tendrils as explants and all of them produced abundant organogenic calli and shoots under proper treatments (Fig. 1c). Tendrils of Passiflora were rarely used in organogenesis, however, In vitro regeneration was achieved in P. trifasciata, $P$. $x$ 'Guglielmo Betto' and $P$. 'Manta' using young tendrils (Pipino et al. 2010). In our present study, tendrils produced abundant organogenic calli and adventitious shoots, which were not significantly different from the other two types of explant except for the fresh weight of callus (Fig. 2).

Besides explants, organogenesis during micropropagation is influenced by many other factors, such as plant growth regulator and their concentration, media composition, and most importantly endogenous cytokinin levels of explants (Gentile et al. 2014). Plant regeneration by organogenesis was successfully established in Passiflora using BA alone and at a wide range of concentrations, most successful cases occurred at low concentration of BA (2.2-8.87 $\mu \mathrm{M})$ (Ozarowski and Thiem 2013). For example, $76 \%$ of leaf segments of $P$. cincinnata formed buds on MS medium supplied with $4.4 \mu \mathrm{M}$ and $5.87 \mu \mathrm{M} \mathrm{BA}$, and $54 \%$ of leaf segments formed buds with $2.2 \mu \mathrm{M} \mathrm{BA}$ (Lombardi et al. 2007). A greater number of shoots of $P$. edulis were obtained on MS medium supplied with $4.4 \mu \mathrm{M}$ and $6.65 \mu \mathrm{M} \mathrm{BA}$ (Prammanee et al. 2011). However, this is different to the findings presented here as organogenesis did not occur with BA alone at any concentration $(2.22,4.44$ or 8.88 $\mu \mathrm{M})$ (Table 2). A possible explanation could be that $P$. Xishuangbannaensis already has high endogenous cytokinin level. The requirement of auxin in combination with cytokinin may regulate the endogenous cytokinin level by the inhibition of cytokinin biosynthesis (Javed et al. 2013). The best callus and shoot induction was achieved in medium supplied with BA $(4.44 \mu \mathrm{M})$ in combination with NAA $(1.08 \mu \mathrm{M})$, in the present study. These results agree with several other findings in Passiflora and other plant species (Komathi et al. 2011; Perveen et al. 2015; Naaz et al. 2019). However, callus and shoot induction failed when a higher dose of BA $(8.88 \mu \mathrm{M})$ in combination with $1.08 \mu \mathrm{M}$ NAA were used.

Various studies have shown that rooting of regenerated Passiflora shoots was observed on 1/2 MS or MS medium without supplementation of plant growth regulators (Pinto et al. 2010; Garcia et al. 2011; Pacheco et al. 2012). However, in the present study, best rooting was observed by transferring the shoots onto a rooting medium containing auxins (1.08 $\mu \mathrm{M}$ NAA). Several previous studies have also demonstrated that low doses of auxins were needed for the rooting of regenerated shoots of Passiflora, such as $P$. foetida, $P$. edulis and $P$. 
edulis f. flavicarpa (Nhut et al. 2007; Prammanee et al. 2011; Ragavendran et al. 2012). When regenerated shoots were kept on media supplied with $4.44 \mu \mathrm{M}$ BA and $1.08 \mu \mathrm{M}$ NAA and after 3 months, no roots formed (data not shown). It could indicate that BA has impeded rooting of regenerated shoots (Gentile et al. 2014).

In contrast to many previous reports on the genetic stability among the micro-propagated plants and mother plants (Venkatachalam et al. 2007; Asthana et al. 2011; Chavan et al. 2015) the present study shows a relatively high level of genetic variation between the mother plants and regenerated tissue. Several reports have shown low percentage of genetic variation of regenerated plants in different species, such as Spilanthes calva (Razaq et al. 2013) and Ansellia africana (Bhattacharyya et al. 2017). High level of genetic variation has been observed in other regeneration systems (Rathore et al. 2011; Rawat et al. 2013). These results indicate the need to test the genetic variability of regenerated plantlets before actual conservation practices.

\section{Conclusions}

The present study was designed to establish a protocol for plant regeneration by organogenesis of $P$. xishuangbannaensis. The maximum callus induction and shoot bud differentiation were both achieved on $1 / 2$ MS medium supplemented with $4.44 \mu \mathrm{M}$ BA and $1.08 \mu \mathrm{M}$ NAA. The best rooting was achieved from 30 -d-old, regenerated shoots on $1 / 2$ MS medium supplemented with NAA $1.08 \mu \mathrm{M}$. Assessment of genetic fidelity of ten regenerated plantlets using ISSR primers revealed a relatively high genetic variation among mother and regenerated plantlets but due to the endangered status of $P$. xishuangbannaensis, this procedure provides a reliable method for its ex situ conservation.

\section{Declarations}

\section{Acknowledgments}

This study was supported by the Science \& Technology Basic Resources Investigation Program of China: Survey and Germplasm Conservation of Plant Species with Extremely Small Populations in South-West China (2017FY100100). The authors would like to thank Dr. Fuchuan Wu for providing plant material.

\section{Conflicts of interests}

The authors have no conflicts of interest to declare that are relevant to the content of this article.

\section{References}

Ahmad N, Faisal M, Anis M et al. (2010) In vitro callus induction and plant regeneration from leaf explants of Ruta graveolens L. South Afr J Bot 76:597-600

Al-Qurainy F, Nadeem M, Khan S et al. (2018) Rapid plant regeneration, validation of genetic integrity by ISSR markers and conservation of Reseda pentagyna an endemic plant growing in Saudi Arabia. Saudi J Biol Sci 25:111-116 
Asthana P, Jaiswal VS, Jaiswal U (2011) Micropropagation of Sapindus trifoliatus L. and assessment of genetic fidelity of micropropagated plants using RAPD analysis. Acta Physiol Plant 33:1821-1829

Ayuso M, García P, Pablo P et al. (2019) In vitro culture of the endangered plant Eryngium viviparum as dual strategy for its ex-situ conservation and source of bioactive compounds. Plant Cell Tiss Org Cult 138:427435

Bairu MW, Aremu AO, Van Staden J (2011) Somaclonal variation in plants: causes and detection methods. Plant Growth Regul 63: 147-173

Bhattacharyya P, Kumar V, Van Staden J (2017) Assessment of genetic stability amongst micropropagated Ansellia africana, a vulnerable medicinal orchid species of Africa using SCoT markers. S Afr J Bot 108:294302

Bornet B, Branchard M (2001) Nonanchored inter simple sequence repeat (ISSR) markers: reproducible and specific tool for genome fingerprinting. Plant Mol Biol Rep 19:209-215

Campbell BC, LeMare S, Piperidis G et al. (2011) IRAP, a retrotransposon-based marker system for the detection of somaclonal variation in barley. Mol Breed 27:193-206

Chavan JJ, Gaikwad NB, Kshirsagar PR et al. (2015) Highly efficient in vitro proliferation and genetic stability analysis of micropropagated Ceropegia evansii by RAPD and ISSR markers: a critically endangered plant of Western Ghats. Plant Biosys 149:442-450

Dias LLC, Santa-Catarina C, Ribeiro DM et al. (2009) Ethylene and polyamine production patterns during in vitro shoot organogenesis of two passion fruit species as affected by polyamines and their inhibitor. Plant Cell Tiss Org Cult 99:199-208

Espinoza TEB, Jørgensen PM, MacDougal JM (2018) A taxonomic revision of Passiflora sect. xerogona (Passifloraceae) using principal component analysis. Ann Missouri Bot Gard 103:258-313

Faria RB, Carvalho IF, Rossi AB et al. (2018) High responsiveness in de novo shoot organogenesis induction of Passiflora cristalina (Passifloraceae), a wild Amazonian passion fruit species. In Vitro Cell Dev Biol Plant 54:166-174

Fernando JA, Vieira MLC, Machado SR et al. (2007) New insights into the in vitro organogenesis process:the case of Passiflora. Plant Cell Tiss Org Cult 91:37-44

Garcia R, Pacheco G, Falcão E et al. (2011) Influence of type of explant, plant growth regulators, salt composition of basal medium, and light on callogenesis and regeneration in Passiflora suberosa $\mathrm{L}$. (Passifloraceae). Plant Cell Tiss Org Cult 106:47-54

Gentile A, Gutiérrez MJ, Martinez J et al. (2014) Effect of metatopolin on micropropagation and adventitious shoot regeneration in Prunus rootstocks. Plant Cell Tiss Org Cult 118:373-381 
González-Benito M, Martín C (2011) In vitro preservation of Spanish biodiversity. In Vitro Cell Dev Biol Plant 47:46-54

Henrique M, Gabriel L, Yesquén C et al. (2020) Endophytic fungi from Passiflora incarnata: an antioxidant compound source. Arch Microbiol 202:2779-2789

Javed SB , Anis BM , Khan BPR et al. (2013) In vitro regeneration and multiplication for mass propagation of Acacia ehrenbergiana Hayne: A potential reclaimant of denude arid lands. Agroforestry Syst 87:621-629

Lima LKS, Jesus ON, Soares TL et al. (2020) Growth, physiological, anatomical and nutritional responses of two phenotypically distinct passion fruit species (Passiflora L.) and their hybrid under saline conditions. Sci Hortic 263:109037. doi:10.1016/j.scienta.2019.109037

Komathi S, Rajalakshmi G, Savetha S et al. (2011) In vitro regeneration of Passiflora foetida L. J Res Biol 8:653-659

Krishna H, Alizadeh M, Singh D et al. (2016) Somaclonal variations and their applications in horticultural crops improvement. 3. Biotech 6:1-18

Krosnick SE (2005) Passiflora xishuangbannaensis (Passifloraceae): A New Chinese Endemic. Novon $15: 160-163$

Krosnick SE, Freudenstein JV (2005) Monophyly and floral character homology of Old World Passiflora (Subgenus Decaloba: Supersection Disemma). Syst Bot 30: 139-152

Kumar P, Gupta JK, Misra AK et al. (2009) Potential of molecular markers in plant biotechnology. J Plant Omics 2:141-162

Lombardi SP, Passos IS, Nogueira MCS et al. (2007) In vitro shoot regeneration from roots and leaf discs of Passiflora cincinnata Mast. Braz Arch Biol Techn 50:239-247

Ma XD, Yan LC, Krosnick SE et al. (2019) Passiflora menghaiensis, a new species of Passifloraceae from Yunnan, China. Taiwania 64:97-102

Martin KP, Pachathundikandi SK, Zhang CL et al. (2006) RAPD analysis of a variant of banana (Musa sp.) cv. Grande Naine and its propagation via shoot tip culture. In Vitro Cell Dev Biol Plant 42:188-192

Mast P, Lombardi SP, Ribeiro I et al. (2007) In vitro shoot regeneration from roots and leaf discs of Passiflora cincinnata Mast. 50:239-247

Murashige T, Skoog FA (1962) Revised medium for rapid growth and bioassays with tobacco tissue cultures. Physiol Plantarum 15473-497

Naaz A, Hussain SA, Anis M et al. (2019) Meta-topolin improved micropropagation in Syzygium cumini and acclimatization to ex vitro conditions. Biol Plant 63:174-182 
Naseer S, Mahmood T (2014) Tissue culture and genetic analysis of somaclonal variations of Solanum melongena L. cv. Nirrala. Cent Eur J Biol 9:1182-1195

Nhut DT, Khiet BLT, Thi NN et al. (2007) High frequency shoot formation of yellow passion fruit (Passiflora edulis $f$. flavicarpa) via thin cell layer (TCL) technology. In Jain SM and Häggman H (eds.), Protocols for micropropagation of woody trees and fruits, Springer, pp. 417-426

Ozarowski M, Thiem B (2013) Progress in micropropagation of Passiflora spp. to produce medicinal plants: a mini-review. Rev Bras Farmacogn 23:937-947

Ozarowski M, Thiem B, Gryszczynska A et al. (2013) Studies on in vitro seed germination and plant regeneration from mature leaf, internodal and petiole explants of Passiflora caerulea L. 56th Convention of the Polish Botanical Society, Interdisciplinary and Practical Significance of Botanical Sciences. Olsztyn, Poland.

Pacheco G, Garcia R, Lugato D et al. (2012) Plant regeneration, callus induction and establishment of cell suspension cultures of Passiflora alata Curtis. Sci Hortic 144:42-47

Perveen S, Khanam MN, Anis M et al. (2015) In vitro mass propagation of Murraya koenigii L. J Appl Res Med Aromat Plants 2:60-68

Phillips R, Kaeppler S, Olhoft P (1994) Genetic instability of plant tissue cultures: breakdown of normal controls. Proc Natl Acad Sci USA 91:5222-5226

Pinto APC, Monteiro-Hara ACA, Stipp LCL et al. (2010) In vitro organogenesis of Passiflora alata. In Vitro Cell Dev Biol Plant 46: 28-33

Pipino L, Braglia L, Giovannini A et al. (2010) In vitro regeneration and multiplication of Passiflora hybrid “Guglielmo Betto". In Jain SM, Ochatt SJ (eds), Protocols for in vitro propagation of ornamental plants. Methods in molecular biology. New Yersey: Humana Press, pp. 153-162

Prammanee S, Thumjamras S, Chiemsombat P et al. (2011) Efficient shoot regeneration from direct apical meristem tissue to produce virus-free purple passion fruit plants. Crop Prot 30:1425-1429

Rahmani M, Pijut PM, Shabanian N et al. (2015) Genetic fidelity assessment of in vitro-regenerated plants of Albizia julibrissin using SCoT and IRAP fingerprinting. In Vitro Cell Dev Biol Plant 51: 407-419

Ragavendran C, Kamalanathan D, Reena G et al. (2012) In vitro propagation of nodal and shoot tip explants of Passiflora foetida L. An exotic medicinal plant. Asian J Plant Sci Res 2:707-711

Rathore NS, Rai MK, Phulwaria M et al. (2014) Genetic stability in micropropagated Cleome gynandra revealed by SCOT analysis. Acta Physiol Plant 36:555-559

Rawat JM, Rawat B, Mehrotra S et al. (2013) ISSR and RAPD based evaluation of genetic fidelity and active ingredient analysis of regenerated plants of Picrorhiza kurroa. Acta Physiol Plant 35:1797-1805 
Razaq R, Heikrujam M, Chetri SK et al. (2013) In vitro clonal propagation and genetic fidelity of the regenerants of Spilanthes calva DC. using RAPD and ISSR marker. Physiol Mol Biol Plants 19:251-260

Rocha DI, Vieira LM, Tanaka FAO et al. (2012) Anatomical and ultrastructural analyses of in vitro organogenesis from root explants of commercial passion fruit (Passiflora edulis Sims). Plant Cell Tiss Org Cult 111:69-78

Rodrigues V, Kumar A, Gokul S et al. (2020) Micropropagation, encapsulation, and conservation of Decalepis salicifolia, a vanillin isomer containing medicinal and aromatic plant. In Vitro Cell Dev Biol Plant 56:526-537

Sousa AGR, Souza MM, Melo CAF et al. (2015) ISSR markers in wild species of Passiflora L. (Passifloraceae) as a tool for taxon selection in ornamental breeding. Genet Mol Res 14:18534-18545

Shekhawat MS, Kannan N, Manokari M et al. (2015) In vitro regeneration of shoots and ex vitro rooting of an important medicinal plant Passiflora foetida L. through nodal segment cultures. J Genet Eng Biotechnol 13:209-214

Siddique I, Anis M, Aref IM (2010) In vitro adventitious shoot regeneration via indirect organogenesis from petiole explants of Cassia angustifolia Vahl., a potential medicinal plant. Appl Biochem Biotechnol 162:2067-2074

Silva CV, Oliveira LS, Loriato VAP et al. (2011) Organogenesis from root explants of commercial populations of Passiflora edulis Sims and a wild passionfruit species, P. cincinnata Masters. Plant Cell Tiss Org Cult 107:407-416

Sousa AGR, Souza MM, Melo CAF et al. (2015) Cross-species amplification of microsatellite loci developed for Passiflora edulis Sims. in related Passiflora species. Genet Mol Res 14:18534-18545

Wang X, Wu R, Lin X et al. (2013) Tissue culture-induced genetic and epigenetic alterations in rice pure-lines, F1 hybrids and polyploids. BMC Plant Biol 13:77. doi:10.1186/1471-2229-13-77

Sun WB, Ma YP, Blackmore S (2019) How a new conservation action concept has accelerated plant conservation in China. Trends Plant Sci 24: 4-6

Sheelavantmath SS, Murthy HN, Pyati AN et al. (2000) In vitro propagation of the endangered orchid, Geodorum densiflorum (Lam.) Schltr. through rhizome section culture. Plant Cell Tiss Org Cult 60:151-154

Venkatachalam L, Sreedhar RV, Bhagyalakshmi N (2007) Micropropagation in banana using high levels of cytokinins does not involve any genetic changes as revealed by RAPD and ISSR markers. Plant Growth Regul 51:193-205

Vianna LS, Santos EA, Viana AP et al. (2019) ISSR and SSR markers for determining genetic relationships among three wild species of Passiflora. Genet Mol Res 18: gmr18040. doi:10.4238/gmr18040

Vieira LM, Rocha DI, Taquetti MF et al. (2014) In vitro plant regeneration of Passiflora setacea DC (Passifloraceae): the influence of explant type, growth regulators, and incubation conditions. In Vitro Cell Dev 
Zietkiewicz E, Rafalaki JA, Labuda D (1994) Genome fingerprinting by simple sequence repeat (SSR)anchored polymerase chain reaction amplification. Genomics 20:176-183

\section{Figures}

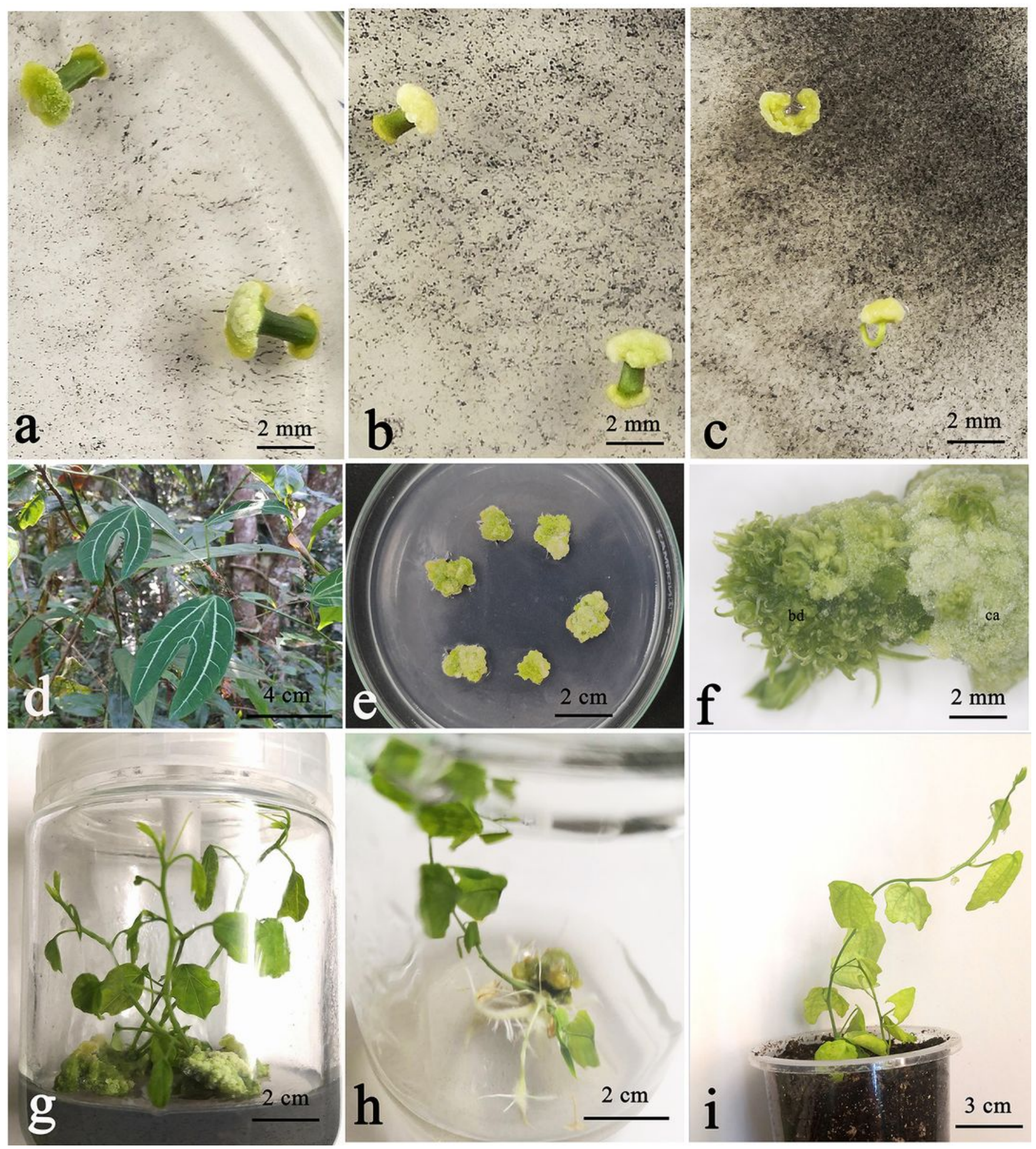

Figure 1 
(a-c) Calli induced from internodal segments (Ins), petioles segments (Pts). and tendrils segments (Tds), respectively. (d) A mature plant of Passiflora xishuangbannaensis. (e) Calli and buds induced from internodal segments explants (Ins) on 1/2 Murashige and Skoog medium (MS) with 6-benzylaminopurine (BA) $4.44 \mu \mathrm{M}$ and naphthaleneacetic acid (NAA) $1.08 \mu \mathrm{M}$, after 45 days of incubation. (f) Details of Figure e showing multiple buds from regenerated callus. Bud (bd); callus (ca). (g) Multiple shoots from Ins on basal medium with BA $4.44 \mu \mathrm{M}+\mathrm{NAA} 1.08 \mu \mathrm{M}$, after 30 days of subculture. (h) Root formation after 30 days of transferring to a rooting medium, i.e. 1/2 MS medium with NAA $1.08 \mu \mathrm{M}$. (i) Acclimatized plants under greenhouse conditions.
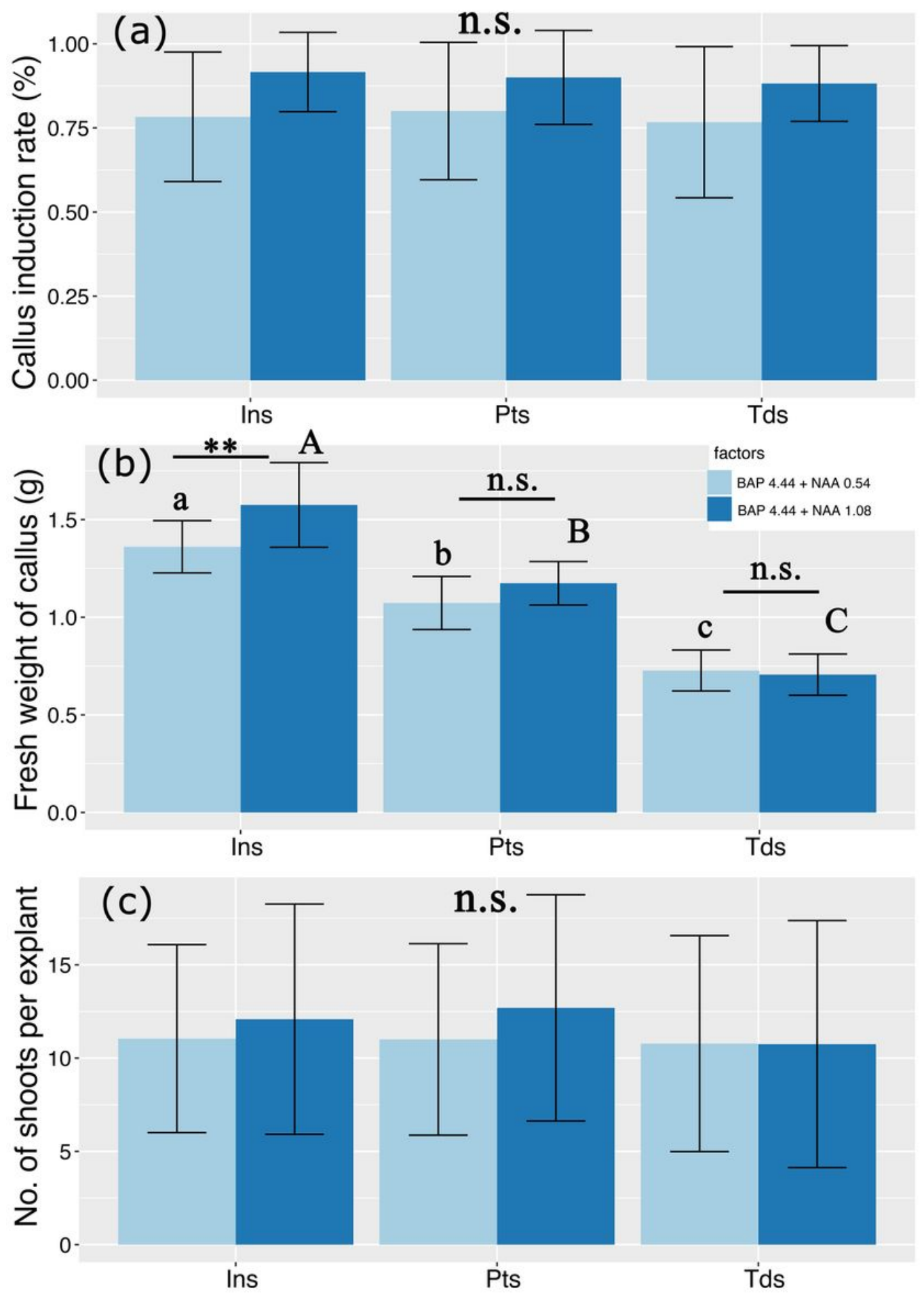
Figure 2

Effect of different explants on callus induction and shoot-bud regeneration from 1/2 Murashige and Skoog (MS) medium with BA $4.44 \mu \mathrm{M}+\mathrm{NAA} 0.54 \mu \mathrm{M}$, or MS with BA $4.44 \mu \mathrm{M}+\mathrm{NAA} 1.08 \mu \mathrm{M}$ after 45 days of incubation. Values are mean $\pm S E$. ** highly significant $(P<0.01)$. n.s. non-significant $(P>0.05)$.

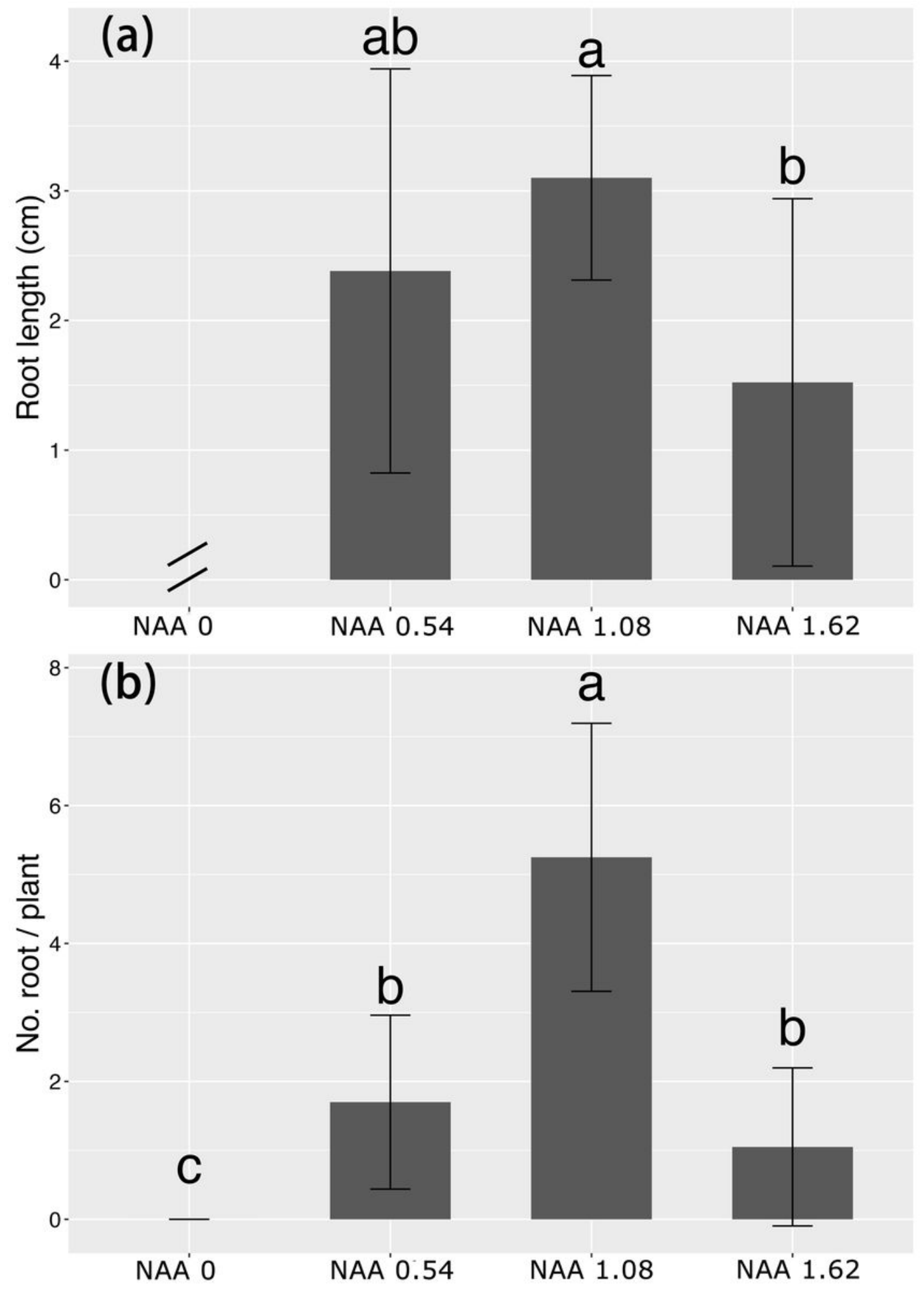

Figure 3

Effects of naphthaleneacetic acid (NAA) on root induction from 30-d-old regenerated shoots after 30 days of incubation. Values are mean \pm SE. Different letters indicate significant differences among treatments $(P<$ 
0.05).

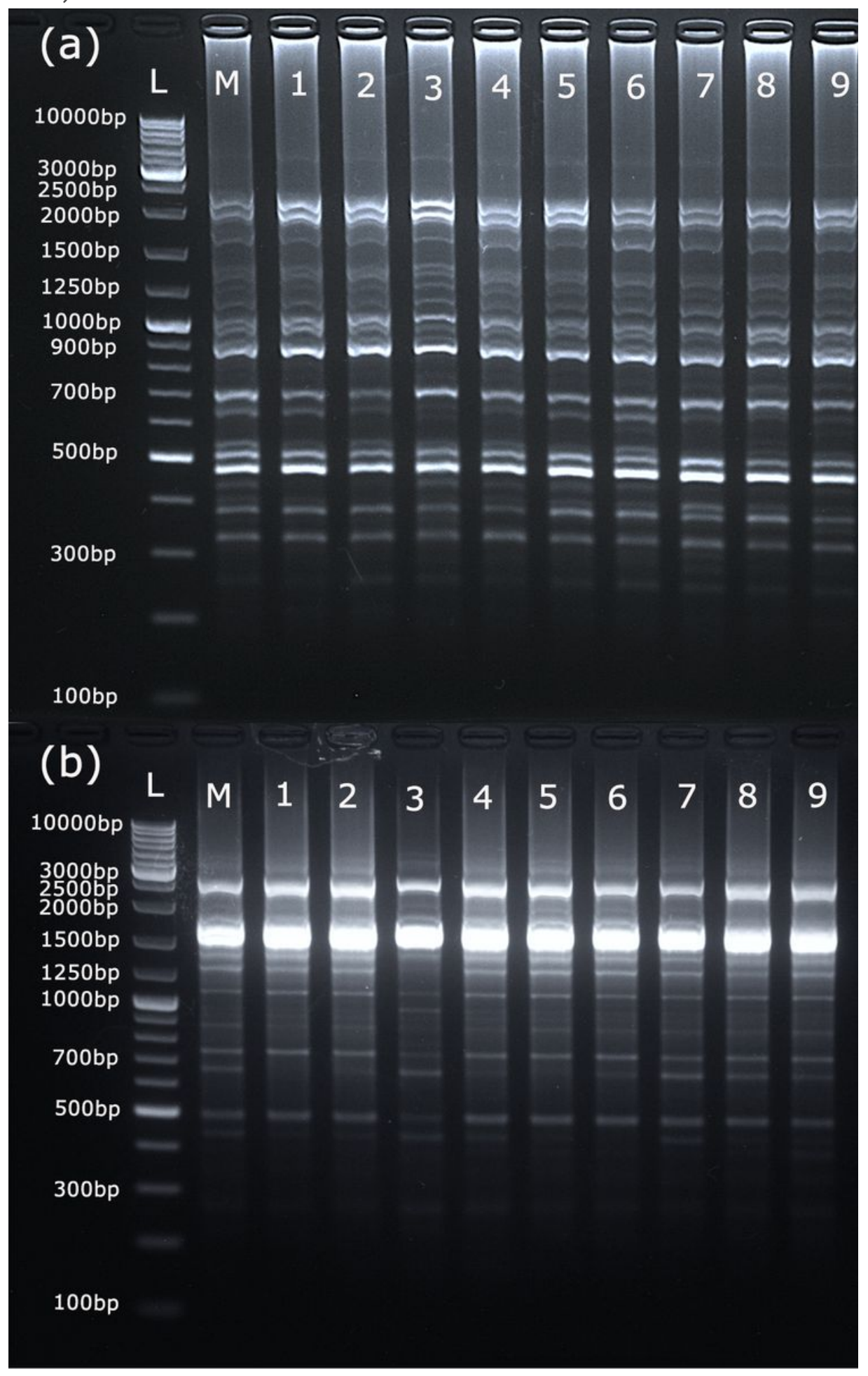

\section{Figure 4}

ISSR amplification products produced using the primer 1 (a) and 3 (b), and separated on a $1.7 \%$ agarose gel. L: 2-log ladder, M: mother plant, 1 to 9: in vitro raised plantlets. 